\title{
Living Cities: Tropical Imaginaries
}

\author{
Anita Lundberg \\ James Cook University Singapore
}

\section{Abstract}

This special issue of eTropic concerns living cities in the tropics and how they are conceived through the imagination. The collection of papers reminds us that urban environments are both created and creative spaces concerned with peopled and lived experiences and their interaction with material, cultural and natural environments. The issue is interested in processes of tropical space and place-making, with an emphasis on key areas that make up lived cities in the tropics: architecture, design, creative industries and economies, circular economy, neoliberalism, displacement, heritage, urban myths, narratives, cultural and natural landscapes, sustainable practices, and everyday life.

Keywords: tropical cities, material culture, imagination, creativity, urbanisation, heritage, mythology, displacement, creative economy, neoliberalism, narratives, sustainability 


\section{'L}

iving Cities: Tropical Imaginaries' reminds us that urban environments are both created and creative spaces. This special issue is Part One of two issues concerned

with the peopled and lived experiences of cities and how these interact with material, cultural and natural environments. The issue is interested in processes of tropical space and place-making, with an emphasis on key areas that make up lived cities in the tropics: architecture, design, creative industries and economies, heritage, urban myths, narratives, cultural and natural landscapes, sustainable practices, and everyday life.

The tropical region covered in the following papers ranges from Hawai'i in the United States, though South, Southeast and East Asia, to the northeast of Australia. The papers, in varying ways, employ case studies of cities, including: Honolulu, Singapore, Hong Kong, Manila, Colombo, and Townsville.

Of particular interest are the variety of theoretical and methodological approaches that the authors have engaged in order to study a particular city and idea - and to bring it to life. These include: critical aesthetics and national discourses, ocularcentrism and feminism, developmental urbanism, design thinking, flânerie, tangible and intangible heritage-making, mythology and archetypal psychology, narrative analysis, non-dualistic philosophy and sustainability.

In the first paper of this special issue, Kelema Lee Moses undertakes a case study of Honolulu's landmark building, the Financial Plaza of the Pacific. She analyses how architecture acts to visually reinforce the long and complex relationship between the Hawaiian Islands and the United States. Her paper demonstrates how a close reading of the building unveils a narrative of Honolulu as a living city of the Pacific in which its people are engaged in complicated mediations between indigenous identity, United States citizenship, public spaces and buildings. Her analysis engages economics, colonialism, policies and Brutalist architecture. She argues that the metropolis itself is never a stable entity but is constantly evolving though the people and spaces of the city.

Nathan Bullock's article takes us to Singapore to examine ocularcentrism through an analysis of the city's architecture. He notes that although the critique of vision - including panoptic vision is well-established in feminist theory, it deserves further articulation in the tropics. Of particular interest in regard to the tropics is how ocularcentrism is embedded in values of Western philosophy and was physically inscribed in colonial city plans. Despite Singapore's postcolonial status, ocularcentrism remains visibly present in Singapore's housing plan, modernist architecture and heritage rejuvenation. His paper articulates a strong critique of ocularcentrism across three arenas of built environment in Singapore - the Housing Development Board public housing, the central business district, and the vernacular architecture of Kampong Glam.

Housing development in the bustling metropolis of Singapore is also the focus of Adrian Kuah's

eTropic: electronic journal of studies in the tropics

https://doi.org/10.25120/etropic.17.1.2018.3638 
paper in this issue. He sets his analysis within the broader developmental framework of the rapid pace of urbanisation, which is particularly striking across the tropical regions of the world. $\mathrm{He}$ argues that housing the massive increase in population is a critical concern for contemporary cities of the tropics. In this regard, Singapore is taken up as a case study of a city that has engineered to provide housing to almost every person through its Housing Development Board scheme. His study of the public housing policy of Singapore covers its historical background from the late colonial period through to early postcolonialism and the present day. Kuah notes that the imaginary of Singapore has been explicitly based in notions of development and modernity, the sustainability of which is coming under focus as questions of environment and heritage surface.

Katja Fleischmann investigates the evolution of design within the innovation space of the city, specifically how it is applied in the buzzing tropical global financial centre of Singapore; and in Townsville, a regional city in Australia's tropical northeast. She demonstrates how design has become an important driver of economic innovation and living, evolving from its popular understanding as a decorative discipline that creates products and drives consumption; to driving social, public and economic change. Singapore has been on the policy forefront to push design-led innovation to facilitate start-ups, spark economic development and re-imagine its future - and on a human scale, harmonize with its tropical environment. Indeed, Design Thinking and Service Design Thinking practices are driving a shift away from unsustainable consumerism towards a Circular Economy. The broader concern of her paper is whether the large scale innovative practices applicable to global cities such as Singapore, can be adopted and adapted to regional Australian cities such as Townsville. She offers a case study of a university student project as an example of this potential.

In the paper by Sneha Chaudhury and Anita Lundberg the rise of the creative city is explored through flânerie. The authors begin by introducing Singapore's desire to become a renaissance city - a global city of the arts, before proceeding to the theory and practice of the flâneur as a qualitative alternative to understanding how the city's people, on the ground, engage creatively. They offer a critique of the flâneur, arguing firstly, that it is based in examples of the global north and thus problematically connected with notions of the colonial metropole; and secondly, that it is entangled with the masculine gaze. They call for future studies based in the imaginaries of tropical flânerie and the flâneuse tropique. Their paper is a perambulation of academic literature that may be taken up as a guide for such future engagements. It explores the notion of the flâneur under the themes of: classic literature, contemporary literature in tropical Asia, feminist critiques and examples, the theory in connection with ethnographic methods, and visual methods through photography.

David Ocón alerts us to a heritage conundrum in densely populated and land-scarce tropical Asian cities where rapid expansion and growth is colliding with legacies and memories of the past. His paper examines three case studies of tangible and intangible heritage-making: To 
Kwa Wan station in Hong Kong; the Rizal monument in Manila; and Bukit Brown Cemetery in Singapore. David acknowledges that the process of heritage-making is far from straightforward and defining the meaning of heritage in young postcolonial nations, with their dense cities, is challenging - involving the intersection of history, religion, memory-shaping, development, and identity-building. He argues that this requires fluent communication channels between civil society, local organisations and governments. His paper sheds light on the policies behind heritage-making, where the interaction with concepts such as memory, identity, urban planning, progress, and nature, creates complex situations and requires imaginative resolutions.

The paper by Michael Joyce offers a connection between a previous issue of eTropic on urban vampires (Lundberg \& Geerlings, 2017) and this issue on living cities and their tropical imaginaries. His paper begins in Singapore with a Facebook post about child organ traffickers at the Malaysia/Thailand border. The post proves a fake, but it leads him to postulate that the myth of the organ trafficker may come from the same bloodline as the myth of the vampire. The paper goes on to outline the vampire myths of Southeast Asia and how such myths are analysed through archetypal theory as manifestations of fears and repressed aspects of life. He notes how contemporary vampires have moved to cities, and argues that they are joined by a modern bloodsucker, the organ harvester. Continuing to delve deeper, the paper links vampiric organ harvesting with neoliberalism, a phenomenon rapidly consuming Southeast Asia cities.

Diotima Chattoraj articulates the experiences, aspirations and challenges encountered by three middle-aged Sri Lankan Tamil displaced persons in Colombo who are reluctant to return to their places of origin in the northern provinces of Sri Lanka. Originally displaced with their families at a young age during the ethnic violence of 1983, they eventually settled and grew up in the capital city of Colombo. Based on open-ended interviews, the paper presents narrative excerpts from the interviewees which provide a picture of how they reconstructed their lives in Colombo and how they believe that integrating into the capital city helped them to aspire to a better future - which would not have been possible in Jaffna, Velanai or Mannar, their places of origin. This has led them to reconsider and renegotiate their relationship with the city of Colombo and their original 'homes'.

In the final paper, Melusine Martin examines foraging in urban settings in tropical North Queensland and more broadly in Australia, as an alternative mode of consumption for city residents. Urban foraging incorporates the practice of gathering indigenous as well as introduced edible plants from parks, streets, railway reserves and other in-between spaces. Melusine articulates the practice within a broader philosophical argument that critiques the dualistic philosophy that continues to underpin western thinking. In this particular case, she is concerned with the culture/nature binarism. In the setting of Australia, she argues that urban foraging is rooted in Indigenous Australian foraging practices. She notes that the urban foraging system, through gathering wild foods, is an attempt to reconnect with nature in the midst of the city. 
This special issue of eTropic has been concerned with tropical space and places and how they are imagined, made, and lived. Cities are not merely dots on maps, they are peopled. The anthropos matters to cities; design and policies need to include people. Underlying the call for papers for this special issue was a sense of urgency that we need a renewed, people-centric conception of the city - and this requires imagination. These papers have taken up that call with a breadth of case studies that have explored cities from Hawai'i at one side of the Pacific, through South, Southeast and East Asia, to northeast Australia on the other side of the Pacific. In the papers we have encountered spaces that are not empty; but rather teaming with multitudes of people and the problematics that they encounter, endure, live through - and imaginatively engage with.

'Living Cities: Tropical Imaginaries' is a two-part special issue. Part One has concentrated on arts and social science imaginings. Part Two, will engage further with tropical imaginings of the living city as they are conceived in the arts and humanities.

\section{References}

Lundberg, A. \& Geerlings, L. (2017). Tropical Liminal: Urban Vampires \& Other Blood-Sucking Monstrosities. eTropic: electronic journal of studies in the tropics. 16 (1), 1-4. http://dx.doi.org/10.25120/etropic.16.1.2017.3574 